\title{
Minimal Standards for Description of New Taxa Within the Genera Moraxella and Acinetobacter: Proposal by the Subcommittee on Moraxella and Allied Bacteria
}

\author{
K. BQVRE AND S. D. HENRIKSEN \\ Institute of Medical Biology, University of Tromsф, Troms $\phi$, Norway, and Kaptein W. Wilhelmsen og \\ Frues Bakteriologiske Institutt, University of Oslo, Norway
}

\begin{abstract}
According to the statutes of the ICSB (Bacteriological Code, 1976 revision), subcommittees should make recommendations on minimal standards for the description of new taxa in their field of taxonomy, for the purpose of establishing validity of publication. It has further been decided by the Editorial Board that IJSB will serve as a forum for discussion of proposals for minimal standards, which are considered tentative until given final approval by ICSB (Int. J. Syst. Bacteriol. 25:96, 1975). The Subcommittee on Moraxella and Allied Bacteria has generally agreed upon recommendations to ICSB on minimal standards for description of new taxa in the genera Moraxella and Acinetobacter, which are herewith presented. The proposal specifies the minimal requirement for tests (or types of test) employed and does not in any way limit the extent of investigations beyond this. Suggestions are welcomed for improvement of the proposed standards and for the possible use of the standards in the description of species and subspecies in other genera with genetic relations to Moraxella and Acinetobacter (e.g., Branhamella, which by some taxonomists may be considered as a partial objective synonym of Moraxella, and hypothetical new genera).
\end{abstract}

The Subcommittee proposes the following minimal standards for description of new taxa within the genera Moraxella and Acinetobacter.

Cellular morphology. Shape, size (in micrometers), planes of division, and tendency to diplo- and chain arrangement are studied in young cultures (as soon as growth becomes visible and after growth for 20 to $24 \mathrm{~h}$ ) in fluid media (broth culture, with 5\% serum if necessary to obtain growth) and on blood agar medium, both by examination of live preparations (preferably by phase-contrast microscopy) and after Gram staining. Examination for capsule formation is performed with India ink, and for poly- $\beta$-hydroxybutyrate inclusions after cultivation in Hutner medium (for formula see below) with ammonium ions as the $\mathrm{N}$ source and $D L-\beta$-hydroxybutyrate as the $C$ source, or, if cultivation fails on this medium, on serum agar with DL- $\beta$-hydroxybutyrate.

(i) Gram-staining: Hucker modification.

Solution A consists of the following: crystal violet (90\% dye content), $2 \mathrm{~g}$; ethanol (95\%), $20 \mathrm{ml}$. Solution B consists of the following: ammonium oxalate, $0.8 \mathrm{~g}$; distilled water, $80 \mathrm{ml}$. Solutions A and B are mixed and stored for 24 $\mathrm{h}$ before use. The resulting stain is very stable.

Iodine solution consists of the following: iodine, $1 \mathrm{~g}$; potassium iodide, $2 \mathrm{~g}$; distilled water, $300 \mathrm{ml}$.
Counterstain consists of the following: safranin (2.5\% solution in $95 \%$ ethanol), $10 \mathrm{ml}$; distilled water, $90 \mathrm{ml}$.

The Gram staining procedure consists of the following steps. (a) Prepare a film on a slide, dry in air, fix by heat. (b) Cover the film with crystal violet stain (solutions $\mathrm{A}+\mathrm{B}$ ) for $1 \mathrm{~min}$. (c) Wash in tap water. (d) Flood with iodine solution for $1 \mathrm{~min}$. (e) Wash in tap water and blot dry with filter paper. (f) Decolorize for $30 \mathrm{~s}$ with gentle agitation in $95 \%$ ethanol and blot dry. (g) Counterstain for 10 to $30 \mathrm{~s}$ with safranin. (h) Wash in tap water, blot dry.

(ii) Examination for capsule formation. For procedure A, prepare a dilute suspension of the organism in a small drop of water on a slide and cover with cover slip. Add one loopful of India ink to the edge of the cover slip. Examine with immersion lens, searching for fields with a suitable mixture of suspension and India ink for easy examination.

For procedure B (method previously described by Butt et al. [4]), place a drop of $6 \%$ glucose on a meticulously cleaned slide. Make a thin suspension of the organism in the drop. Add a small drop of India ink, mix well with the suspension, and spread the mixture on the slide using the edge of a glass slide as in the preparation of a blood film. Allow the film to dry and counterstain with equal parts of Loef- 
fler methylene blue (KOH [0.01\%], $100 \mathrm{ml}$ plus saturated solution of methylene blue in $96 \%$ ethanol, $30 \mathrm{ml}$ ) and methanol. Wash with water and dry in air without blotting.

(iii) Examination for poly- $\beta$-hydroxybutyrate inclusions. Hutner medium, slightly modified by Cohen-Bazire et al. (9) and by Stanier et al. (23). Most of the ingredients are made up beforehand in the form of the following three stock solutions. Solution A is $\mathrm{Na}_{2} \mathrm{HPO}_{4}+$ $\mathrm{KH}_{2} \mathrm{PO}_{4}$ buffer ( $\mathrm{pH} \mathrm{6.8),} 1 \mathrm{M}$. Solution $\mathrm{B}$ is $\left(\mathrm{NH}_{4}\right)_{2} \mathrm{SO}_{4}, 10 \%$ (wt/vol) aqueous solution. Solution $\mathrm{C}$ consists of the following: nitrilotriacetic acid, $10 \mathrm{~g} ; \mathrm{MgSO}_{4} \cdot 7 \mathrm{H}_{2} \mathrm{O}, 29.56 \mathrm{~g} ; \mathrm{CaCl}_{2}$. $2 \mathrm{H}_{2} \mathrm{O}, 3.335 \mathrm{~g} ;\left(\mathrm{NH}_{4}\right)_{6} \mathrm{Mo}_{7} \mathrm{O}_{24} \cdot 4 \mathrm{H}_{2} \mathrm{O}, 9.25 \mathrm{mg}$; $\mathrm{FeSO}_{4} \cdot 7 \mathrm{H}_{2} \mathrm{O}, 99 \mathrm{mg}$; metals " 44 ," $50 \mathrm{ml}$; distilled water to $1,000 \mathrm{ml}$.

In preparing solution $\mathrm{C}$ dissolve the nitrilotriacetic acid and neutralize with $\mathrm{KOH}$ (about $7.3 \mathrm{~g}$ ), and then add the rest of the ingredients. Adjust the $\mathrm{pH}$ to 6.6 to 6.8 before adjusting to volume.

Metals "44" contains per $100 \mathrm{ml}$ : ethylenediaminetetraacetic acid, $250 \mathrm{mg} ; \mathrm{ZnSO}_{4} \cdot 7 \mathrm{H}_{2} \mathrm{O}$, $1,095 \mathrm{mg}$ ( $250 \mathrm{mg}$ of $\mathrm{Zn}$ ); $\mathrm{FeSO}_{4} \cdot 7 \mathrm{H}_{2} \mathrm{O}, 500 \mathrm{mg}$ (100 mg of Fe); $\mathrm{MnSO}_{4} \cdot \mathrm{H}_{2} \mathrm{O}, 154 \mathrm{mg}$ (50 mg of $\mathrm{Mn}$ ); $\mathrm{CuSO}_{4} \cdot 5 \mathrm{H}_{2} \mathrm{O}, 39.2 \mathrm{mg}(10 \mathrm{mg}$ of $\mathrm{Cu}$ ); $\mathrm{Co}\left(\mathrm{NO}_{3}\right)_{2} \cdot 6 \mathrm{H}_{2} \mathrm{O}, 24.8 \mathrm{mg}\left(5 \mathrm{mg}\right.$ of $\mathrm{Co}$ ); $\mathrm{Na}_{2} \mathrm{~B}_{4} \mathrm{O}_{7}$. $10 \mathrm{H}_{2} \mathrm{O}, 17.7 \mathrm{mg}$ ( $2 \mathrm{mg}$ of $\mathrm{B}$ ). Add a few drops of sulfuric acid to retard precipitation.

To prepare 1 liter of the complete medium, mix $40 \mathrm{ml}$ of solution $A, 2 \mathrm{ml}$ of solution, $\mathrm{B}$, and $20 \mathrm{ml}$ of solution $\mathrm{C}$ and dilute with distilled water, after which add $5 \mathrm{~g}$ of $\mathrm{DL}-\beta$ hydroxybutyrate (23). A copious precipitate forms when this medium is autoclaved but redissolves on cooling.

If the organism fails to grow in this medium, use $10 \%$ serum-nutrient agar slants containing $0.5 \% \mathrm{DL}-\beta$-hydroxybutyrate instead.

(iv) Staining procedure. Daily for 5 days, inclusions are looked for in viable preparations on slides under cover slips by phase-contrast microscopy with an oil immersion objective and by staining for lipid inclusions using the staining method of Burdon (3). The steps for this procedure are as follows. (a) Prepare a film, let dry in air, and fix by heat. (b) Flood the entire slide with Sudan black B solution $(0.3 \mathrm{~g}$ of the powdered stain in $100 \mathrm{ml}$ of $70 \%$ ethanol) and allow the slide to remain undisturbed at room temperature for 5 to $15 \mathrm{~min}$. (c) Drain off excess stain and blot the slide thoroughly dry. (d) Clear the slide with xylene by dipping it in and out of the solvent in a Coplin jar or by adding xylene from a dropping bottle. Blot the cleared slide dry. (e) Counterstain with safranin $(0.5 \%$ aqueous solution) or with dilute carbol fuchsin (Ziehl-Neelsen carbol fuchsin diluted 1:10 with distilled water) for 1 to $3 \mathrm{~min}$. (f) Wash in water, blot, and dry the slide.

Positive control: Moraxella osloensis.

Colony morphology. Include in the description the diameter of colonies of 18 to $20 \mathrm{~h}$ and 48-h blood agar cultures. Note any "pitting" or "corrosion" of the agar. Incubate cultures for several days in a humid atmosphere and observe for surface spreading. Authors should specify exact details of temperature, media, and conditions of incubation in their description.

Motility. Examine for swimming motility in hanging drop preparations of young cultures, incubated at 35 to $37 \mathrm{C}$ and at lower temperature $(30$ to $33 \mathrm{C}, 22 \mathrm{C}$ ). If positive, search for flagella by electron microscopy or after flagellar staining (18). An optional procedure is examination for twitching motility (12).

Oxidase reaction. The following two methods should be used. (a) Test with tetramethyl-pphenylenediamine by the method of Kovacs (16): Smear bacteria collected from an 18- to $20-$ $\mathrm{h}$ blood agar culture with a platinum (not nichrome) loop on to filter paper moistened with a freshly prepared $1 \%$ (wt/vol) aqueous solution of the reagent; development of a purple color within $10 \mathrm{~s}$ constitutes a positive reaction. (b) Test with dimethyl-p-phenylenediamine (1\% [wt/vol] aqueous solution; the solution can be used until it turns brownish). Use either the Kovács method or drop the reagent on to 18- to 20-h blood agar cultures. In the latter case a purplish color turning black within 1 to $2 \mathrm{~min}$ is a positive reaction.

Catalase reaction. Collect bacteria with a glass rod (not platinum loop) from an 18- to 20-h culture on heated blood agar (chocolate agar) or nutrient agar; deposit them in a pile on a slide and cover with $3 \%$ hydrogen peroxide. A positive reaction is indicated by prompt evolution of bubbles of gas. Weakly positive reactions may be disclosed by trapping the gas with a cover slip.

Pigment production. A subjective evaluation based on observation of cultures on different media is acceptable.

Hemolysis. Observe changes around or under single colonies of aerobic surface cultures on $5 \%$ blood agar, preferably with erythrocytes of various animal species (e.g., human, rabbit, ox, sheep, horse). Discoloration of heated blood agar (chocolate agar) should be noted.

Growth requirements. (i) Culture medium. Record the presence or absence of growth in the following media: chocolate agar, $5 \%$ blood agar, nutrient (infusion) agar, $5 \%$ serum broth, nutrient (infusion) broth, $1 \%$ (wt/vol) peptone water, and chemically defined media, e.g., 
Koser citrate medium and Hutner medium [for this purpose modified to contain $1 \mathrm{~g}$ of $\left(\mathrm{NH}_{4}\right)_{2}{ }^{-}$ $\mathrm{SO}_{4}$ per liter as the $\mathrm{N}$ source and $0.2 \%(\mathrm{wt} / \mathrm{vol}$ ) of acetate as the $\mathrm{C}$ source]. Transfer the organism in fluid medium for three passages, starting with a fairly heavy inoculum and continuing with a small inoculum. Watch each passage for at least 4 days for growth (increasing turbidity).

Optional: Requirement for serum can be confirmed by the following test. Use a medium consisting of the following: proteose peptone no. 3 (Difco), $10 \mathrm{~g} ; \mathrm{NaCl}, 5 \mathrm{~g}$; distilled water, 1,000 $\mathrm{ml}$ (pH 7.6). To one out of two $10-\mathrm{ml}$ tubes of the medium add 1 drop of Tween 80 (dissolved to $5 \%$ in distilled water). Inoculate each tube with 1 drop of culture (containing at most $0.5 \%$ serum) or a light suspension of the organism. Incubate for 4 days. If the organism grows well in the medium with Tween added and not without, it is serophilic.

(ii) Atmosphere (relation to oxygen, $\mathrm{CO}_{2}$, and humidity). Determine strict aerobiosis by the following two criteria: (a) growth on a solid medium (preferably without blood) in air, and (b) no growth on the same medium in a controlled anaerobic jar (include a known aerobic control culture).

Study the relation to $\mathrm{CO}_{2}$ by comparing two parallel cultures on blood agar plates in jars, one containing normal atmosphere, the other containing an extra $10 \% \mathrm{CO}_{2}$. The comparison should include the number of single colonies growing from identical inocula and the diameters of growing colonies.

Study the influence of humidity by comparing growth in humid (closed jar with water in the bottom) and dry (ordinary incubator) atmospheres.

(iii) Temperature (minimum, optimum, maximum). Record growth or no growth in an appropriate fluid medium and on blood agar plates at refrigerator temperature $(4 \mathrm{C})$ and at 22,30 to 33,35 to 37 , and $42 \mathrm{C}$. If the organism requires or prefers a humid atmosphere, incubate cultures on blood agar in a closed jar with water in the bottom at temperatures above 30 C. Continue incubation for at least 5 days at the extreme temperatures.

Survival of cultures. Subcultivate from blood agar cultures kept stored in a humid atmosphere at 4 and $22 \mathrm{C}$ and at optimum growth temperature, and determine the approximate time when cultures become sterile.

Hydrolytic and proteolytic degradative activities. (i) Carbohydrates. Production of acid or acid and gas from glucose, maltose, sucrose, lactose, mannitol, arabinose, xylose, galactose, rhamnose, mannose, and fructose.
Methods include using 1\% (wt/vol) peptone water with $1 \%(\mathrm{wt} / \mathrm{vol}$ ) sugar and indicator, e.g., bromothymol blue or Andrade indicator. Repeat tests in Hugh and Leifson O-F medium with the same sugars (glucose with and without vaseline seal). Read daily for 14 days.

If acid production occurs from glucose, perform the Voges-Proskauer reaction (Barritt modification). Cultivate in Clark and Lubs medium (glucose, 5 g; peptone, $5 \mathrm{~g} ; \mathrm{K}_{2} \mathrm{HPO}_{4}, 5$ $\mathrm{g}$; distilled water, $1,000 \mathrm{ml}$ ) for 2 and 4 days at $30 \mathrm{C}$. Test for acetylmethylcarbinol by the method of Barritt (1): To $1 \mathrm{ml}$ of culture add 0.6 $\mathrm{ml}$ of 5\% $\alpha$-naphthol in ethanol and $0.2 \mathrm{ml}$ of $40 \% \mathrm{KOH}$. Shake well and observe for development of pink color in the course of a few minutes. Maximum color development occurs after about $1 \mathrm{~h}$.

(ii) Nitrate and nitrite reduction. Methods include the use of tubes of $1 \%$ ( $\mathrm{wt} / \mathrm{vol}$ ) peptone water, if necessary with $5 \%$ serum, with $0.1 \%$ potassium nitrate and $0.03 \%$ sodium nitrite, respectively, and with a Durham tube in each tube. Incubate for up to 5 days. Test for nitrite with either one of two sets of reagents. (a) Solution A consists of $0.8 \%$ sulfanilic acid in $5 \mathrm{~N}$ acetic acid. Dissolve by gentle heating. Solution $B$ consists of $0.5 \% \alpha$-naphthylamine in $5 \mathrm{~N}$ acetic acid. Dissolve by gentle heating (10). (b) Solution $\mathbf{A}$ is the same as above. Solution B consists of $0.5 \%$ 1-naphthylamine-7-sulfonic acid (Cleve acid).

The second alternative (b) is preferable since Cleve acid is not carcinogenic like $\alpha$-naphthylamine (20). To 5 to $7 \mathrm{ml}$ of culture add $1 \mathrm{ml}$ of solution $A$ and $1 \mathrm{ml}$ of solution $B$. Before adding reagents note the presence of any gas in the Durham tube. A red color after addition of the reagents shows the presence of nitrite.

To tubes not showing red color in the nitrate reduction test add powdered zinc (up to $5 \mathrm{mg}$ / $\mathrm{ml}$ of culture) and allow to stand. Red color indicates nitrate present in the medium, i.e., not reduced. Absence of red color indicates nitrate absent, i.e., reduced to nitrite which in turn has been further reduced.

Note that incubation for 5 days is unnecessary with many organisms. Controls: Moraxella nonliquefaciens ATCC $19975=$ NCTC 10464 (nitrate reduced to nitrite), Acinetobacter calcoaceticus (nitrate not reduced).

(iii) Proteolytic enzymes. Methods include cultivation on Loeffler serum slants for at least 21 days. Cultivate in $15 \%(\mathrm{wt} / \mathrm{vol})$ gelatin tubes (nutrient broth base, if necessary, with 5\% serum) for at least 21 days, in stab culture kept at $22 \mathrm{C}$, or higher temperature, if no growth.

To test for indole production, to 1-, 2-, and 
3-day-old cultures in peptone water (e.g., proteose peptone, tryptone, or casein digest peptone), if necessary with $5 \%$ serum, add $0.5 \mathrm{ml}$ of Kovács (14) reagent (paradimethylaminobenzaldehyde, $5 \mathrm{~g}$; amyl alcohol, $75 \mathrm{ml}$; concentrated $\mathrm{HCl}, 25 \mathrm{ml}$ ) and shake well. A red color in the alcohol layer is a positive reaction. Optional are the following tests. (a) If tests with Kovács reagent are negative, cultures may be tested with Ehrlich reagent (paradimethylaminobenzaldehyde, $1 \mathrm{~g}$; ethanol, $95 \mathrm{ml}$; concentrated $\mathrm{HCl}, 20 \mathrm{ml}$ ). Add the reagent carefully along the side of the tube so as to form a layer on top of the culture. A red color at the interface is a positive reaction. (b) Extract the culture with about $1 \mathrm{ml}$ of xylene with shaking. Add $0.5 \mathrm{ml}$ of Ehrlich reagent (see above). A red color is a positive reaction. For a positive control, use the strain of Bijsterveld (2).

To test for $\mathrm{H}_{2} \mathrm{~S}$ production, inoculate a tube of triple sugar iron agar (TSI) by stabbing the butt and streaking the slope. Observe daily for up to 7 days for blackening due to $\mathrm{H}_{2}$ S production. TSI agar consists of the following: beef extract, $3 \mathrm{~g}$; yeast extract, $3 \mathrm{~g}$; peptone, $20 \mathrm{~g}$; glucose, $1 \mathrm{~g}$; lactose, $10 \mathrm{~g}$; sucrose, $10 \mathrm{~g} ; \mathrm{FeSO}_{4}$. $7 \mathrm{H}_{2} \mathrm{O}, 0.2 \mathrm{~g} ; \mathrm{NaCl}, 5 \mathrm{~g} ; \mathrm{Na}_{2} \mathrm{~S}_{2} \mathrm{O}_{3} \cdot 5 \mathrm{H}_{2} \mathrm{O}, 0.3 \mathrm{~g}$; agar, $20 \mathrm{~g}$; distilled water, $1,000 \mathrm{ml}$; phenol red ( $0.2 \%$ solution), $12 \mathrm{ml}$. Heat to dissolve the solids in the water, add the indicator, mix, and tube. Sterilize at $115 \mathrm{C}$ for $20 \mathrm{~min}$ and cool to form slopes with deep butts.

For an optional replacement of the TSI test for $\mathrm{H}_{2} \mathrm{~S}$ production, grow the organism in cysteine nutrient broth (if necessary, with 5\% serum) and insert a lead acetate paper (10) between the cap or plug and the tube. Examine daily for 7 days for blackening of the paper. The value of a positive reaction in this test has been disputed by some.

To test for urease, heavily inoculate a slope of Christensen (8) medium and observe for 3 days. Development of a red color is a positive reaction. Christensen medium consists of the following: peptone, $1 \mathrm{~g}$; NaCl, $5 \mathrm{~g} ; \mathrm{KH}_{2} \mathrm{PO}_{4}$, $2 \mathrm{~g}$; agar, $20 \mathrm{~g}$; distilled water, $1,000 \mathrm{ml}$. Dissolve ingredients by heating, adjust to $\mathrm{pH} 6.8$, and sterilize at $115 \mathrm{C}$ for $20 \mathrm{~min}$.

Add glucose $(1 \mathrm{~g})$ and phenol red $(0.2 \%$ solution, $6 \mathrm{ml}$ ) to molten base, steam for $1 \mathrm{~h}$, and cool to 50 to $55 \mathrm{C}$.

Sterilize a $20 \%$ urea solution $(100 \mathrm{ml})$ by filtration and add aseptically to the base. Distribute aseptically into tubes and cool as slopes.

Deamination of phenylalanine and tryptophan: Method. Prepare $0.1 \%$ solutions of $\mathrm{L}$ phenylalanine and L-tryptophan, or $0.2 \%$ solutions of the DL-form (the tryptophan will not dissolve completely). The solutions can be pre- served with merthiolate $(0.01 \%)$. Pipette 0.2 to $0.5 \mathrm{ml}$ of the solution into culture tubes. Make a heavy suspension (at least $5 \times 10^{10}$ bacteria per $\mathrm{ml}$ ) in the solution. Place the tubes nearly flat on the bench at room temperature with as large a surface area as possible for $4 \mathrm{~h}$, after which add 2 to 5 drops of $10 \% \mathrm{FeCl}_{3}$. A green color which develops immediately and fades within minutes is a positive phenylalanine reaction. A cherry red color which does not fade is a positive reaction with tryptophan. With the phenylalanine reaction, only a dark green color may be of taxonomic interest, whereas a faint green color may be of little interest. The tryptophan reaction appears to be less sensitive, or more specific, and only gives a red color when the phenylalanine reaction shows a dark green color. Positive control, Moraxella phenylpyrouvica ATCC 23333 = NCTC 10526; negative control, e.g., Moraxella osloensis.

Deamination of phenylalanine and tryptophan: Alternative method. Method of Goldin and Glenn (11). Soak filter paper strips ( 7 by 60 $\mathrm{mm}$ ) in a solution of $0.5 \%$ L-phenylalanine in phosphate buffer (pH 7.4). Dry the strips at room temperature and store in screw-cap tubes. Kept in this manner there are no signs of deterioration after 6 months of storage at room temperature. Make tryptophan strips similarly by soaking strips in $1 \%$ L-tryptophan. Emulsify a loopful of culture from a Kligler iron agar or TSI agar slant in $0.2 \mathrm{ml}$ of saline in a small test tube ( 10 by $75 \mathrm{~mm}$ ). Place a phenylalanine or tryptophan strip in the suspension of bacteria and place the tube in a water bath at $37 \mathrm{C}$ for 1 to $2 \mathrm{~h}$. Add a drop of ferric chloride solution (8\% aqueous) to the filter strip, still immersed in the bacterial suspension. A green color which fades rapidly is a positive reaction with phenylalanine. A brown color which persists is a positive reaction with tryptophan.

This alternative latter method appears to be somewhat less sensitive than the first method described above.

Sensitivity to commonly used antibacterial agents. Determine minimum inhibitory concentrations on the basis of a dilution method with known concentrations of antibiotic in suitable solid or fluid media. Choose the concentrations by the method of Rogosa et al. (21). Benzylpenicillin (penicillin $G$ ) has to be included in the test.

To test for penicillinase production, from a penicillin-sensitive culture of Micrococcus luteus prepare a suspension and spread it on the surface of a Penassay agar (Difco) plate containing 1 unit of penicillin per $\mathrm{ml}$. After drying the plate, inoculate the strains to be tested on to the surface as radial streaks. A 
positive reaction for penicillinase is shown by growth of the micrococcus around the streak within 4 days at $30 \mathrm{C}$.

The following two tests should be included in the minimal. standards when the methods become generally available, or when reference laboratories which can undertake these tests have been established. Whenever possible the tests should be carried out.

Determination of mol \% guanine + cytosine of deoxyribonucleic acid. Any of three methods are satisfactory when used by experienced investigators: chemical determinations of separated bases (17), physical determinations from buoyant density in $\mathrm{CsCl}$ gradients (22), or physical determinations from the thermal denaturation temperature (19). The determinations should include comparison with Escherichia coli $\mathrm{K}-12$ and with strains previously used in other investigations, with the same or different methods.

Estimation of relationship to known, presumably related taxa by means of genetic transformation $(5,6,14)$ and/or nucleic acid hybridization (DNA-DNA [13] or RNA-DNA [7]). The following tests are desirable, but not mandatory: comparison with known, presumably related, taxa of fatty acid composition by gas liquid chromatography; electron microscopy of bacterial sections for determination of the profile pattern of the cell wall, and of negatively stained preparations for detection of fimbriae (pili) and other extracellular structures.

\section{REPRINT REQUESTS}

Address reprint requests to: Dr. K. Bøvre, Institute of Medical Biology, University of Tromse, Tromsø, Norway.

\section{LITERATURE CITED}

1. Barritt, M. M. 1936. The intensification of the VogesProskauer reaction by the addition of $\alpha$-naphthol. J. Pathol. Bacteriol. 42:441-454.

2. Bijsterveld, O. P. van. 1970. New Moraxella strain isolated from angular conjunctivitis. Appl. Microbiol. 20:405-407.

3. Burdon, K. L. 1946. Fatty material in bacteria and fungi revealed by staining dried, fixed slide preparations. J. Bacteriol. 52:665-678.

4. Butt, E. M., C. W. Bonynge, and R. L. Joyce. 1936. The demonstration of capsules about hemolytic streptococci with India ink or azo blue. J. Infect. Dis. 58:5-9.

5. Bøvre, K. 1964. Studies on transformation in Moraxella and organisms assumed to be related to Moraxella. 1. A method for quantitative transformation in Moraxella and Neisseria, with streptomycin resistance as the genetic marker. Acta Pathol. Microbiol. Scand. 61:457-473.

6. Bøvre, K. 1965. Studies on transformation in Moraxella and organisms assumed to be related to Moraxella. 3. Quantitative streptomycin resistance transformation between Moraxella bovis and Moraxella non- liquefaciens strains. Acta Pathol. Microbiol. Scand. 63:42-50.

7. Bøvre, K. 1970. Pulse-RNA-DNA hybridization between rodshaped and coccal species of the MoraxellaNeisseria groups. Acta Pathol. Microbiol. Scand. 76:565-574.

8. Christensen, W. B. 1946. Urea decomposition as a means of differentiating Proteus and paracolon cultures from each other and from Salmonella and Shigella. J. Bacteriol. 52:461-466.

9. Cohen-Bazire, G., W. R. Sistrom, and R. Y. Stanier. 1957. Kinetic studies of pigment synthesis by nonsulphur purple bacteria. J. Cell. Comp. Physiol. 49:25-68.

10. Cowan, S. T. 1974. Cowan \& Steel's manual for the identification of medical bacteria, 2nd ed. Cambridge University Press, Cambridge.

11. Goldin, M., and A. Glenn. 1962. A simple phenylalanine strip method for identification of Proteus strains. J. Bacteriol. 84:870-871.

12. Henrichsen, J. 1972. Bacterial surface translocation. $A$ survey and a classification. Bacteriol. Rev. 36: 478-503.

12a. Holt, J. G. 1975. Editorial Board of the International Journal of Systematic Bacteriology. Minutes of the Meeting, 2 September 1974. Int. J. Syst. Bacteriol. 25:96.

13. Johnson, J. L., R. S. Anderson, and E. J. Ordal 1970. Nucleic acid homologies among oxidase-negative Moraxella species. J. Bacteriol. 101:568-573.

14. Juni, E. 1972. Interspecies transformation of Acinetobacter: genetic evidence for a ubiquitous genus. J. Bacteriol. 112:917-931.

15. Kovács, N. 1928. Eine vereinfachte Methode zum Nachweis der Indolbildung durch Bakterien. Z. Immunitaetsforsch. 55:311-315.

16. Kovács, N. 1956. Identification of Pseudomonas pyocyanea by the oxidase reaction. Nature (London) 178:703.

16a. Lapage, S. P., P. H. A. Sneath, E. F. Lessel, V. B. D. Skerman, H. P. R. Seeliger, and W. A. Clark (ed.). 1975. International code of nomenclature of bacteria and statutes of the International Committee on Systematic Bacteriology and statutes of the Bacteriology Section of the International Association of Microbiological Societies. American Society for Microbiology, Washington, D.C.

17. Lee, K. Y., R. Wahl, and E. Barbu. 1956. Contenu en bases puriques et pyrimidiques des acids désoxyribonucléiques des bactéries. Ann. Inst. Pasteur Paris 91:212-224.

18. Leifson, E. 1960. Atlas of bacterial flagellation. Academic Press Inc., New York.

19. Marmur, J., and P. Doty. 1962. Determination of the base composition of deoxyribonucleic acid from its thermal denaturation temperature. J. Mol. Biol. 5:109-118.

20. Parráková, E., J. Mayer, and J. Janusková. 1969. Die Bestimmung der Nitratreduktion durch Bakterien der Familie Enterobacteriaceae vom Standpunkte der Karzinogenităt der Reagenzien. Arch. Hyg. 153:230-233.

21. Rogosa, M., M. I. Krichevsky, and R. R. Colwell. 1971. Method for coding data on microbial strains for computers (edition AB). Int. J. Syst. Bacteriol. 21:A1-A175.

22. Schildkraut, C. L., J. Marmur, and P. Doty. 1962. Determination of the base composition of deoxyribonucleic acid from its buoyant density in $\mathrm{CsCl}$. $\mathrm{J}$. Mol. Biol. 4:430-443.

23. Stanier, R. Y., N. J. Palleroni, and M. Doudoroff. 1966. The aerobic pseudomonads: a taxonomic study. J. Gen. Microbiol. 43:159-271. 